\title{
On the road performance simulation of hydrogen and hybrid cars
}

\author{
Sørensen, Bent
}

Published in:

Proc. "World Hydrogen Technology Conference, Singapore"

Publication date:

2005

Document Version

Publisher's PDF, also known as Version of record

Citation for published version (APA):

Sørensen, B. (2005). On the road performance simulation of hydrogen and hybrid cars. In Proc. "World Hydrogen Technology Conference, Singapore" (pp. A16-230). Nanyang Technological University.

\section{General rights}

Copyright and moral rights for the publications made accessible in the public portal are retained by the authors and/or other copyright owners and it is a condition of accessing publications that users recognise and abide by the legal requirements associated with these rights.

- Users may download and print one copy of any publication from the public portal for the purpose of private study or research.

- You may not further distribute the material or use it for any profit-making activity or commercial gain.

- You may freely distribute the URL identifying the publication in the public portal.

Take down policy

If you believe that this document breaches copyright please contact rucforsk@kb.dk providing details, and we will remove access to the work immediately and investigate your claim. 


\title{
On the road performance simulation of hydrogen and hybrid cars
}

\author{
Bent Sørensen \\ Roskilde University \\ Institute of Mathematics \& Physics, Energy \& Environment group \\ Universitetsvej 1, Bld. 27.2, DK-4000 Roskilde Denmark \\ boson@ruc.dk http://mmf.ruc.dk/energy
}

\begin{abstract}
An assessment is made of on-the-road performance, for a pure fuel cell car, a pure battery operated car, and a fuel cell-battery hybrid car. The tool used for this study is the modular software-package ADVISOR [1], which is well tested and offer a range of simple, parametrised sub-models or more detailed physical models for the fuel cell stack, the batteries, the electric motor, the exhaust control, the transmission and entire power train including controls and control strategies. The basis configurations of the cars modelled is characterised by high energy efficiency, before adding a fuel cell and electric motor also of high conversion efficiencies. Preceding the presentation of results, the best way to characterise energy efficiency is discussed.
\end{abstract}

\section{Vehicle performance and energy effi- ciency}

The efficiency of driving a road vehicle depends in part on the technical features of the vehicle, such as energy conversion and transmission efficiencies, and partly on factors deriving from driving cycle and driving style. The interface between the road, weather and vehicle factors include air and surface resistance, and driving style exhibits a subtle interaction with the technical design of the vehicle (part load engine efficiencies, assistance say in shutting engine off rather than idling, brake power recovery, etc.) [2].

It is customary to quote the relationship between energy input to the vehicle and a given length of a trip involving a predefined standard driving cycle specified by speed as a function of time and road conditions (slopes, surface types, wind speeds). For licens- ing purposes (including not only safety but also in many countries car taxation fixation, which increasingly is linked to car efficiency), vehicle performance under idealised driving cycles are been measured and published at annual intervals [3]. Figure 1 gives the 2005 results for selected cars already on the market, as function of payload, showing the great variations in efficiency for a car with a given payload, as well as the general decline of this measure of efficiency with increasing payload.

A better way to characterise the vehicle efficiency is to relate the energy input to the actual work being performed. Traffic work may be defined as the number of kilometres driven (along a given driving cycle) times the payload carried, i.e. $\mathrm{km}$ times $\mathrm{kg}$. I use this index defined in terms of the maximum permissible payload for a given vehicle. The maximum payload is the difference between the maximum total mass of the vehicle loaded with passengers and freight, and its proper mass. This number is usually specified in the licensing certificate for the vehicle and is generally available in sales material for cars in Europe [4]. Alternative definitions include a further factor describing the average occupancy over time in terms of payload as a fraction of the maximum permitted, or simplified the occupancy taken as the average number of passengers relative to the maximum that the vehicle is designed to carry. Most of the cars selected for Figures 1 and 2 (see Table 1) are designed for a maximum of 5 passengers, with the exception of the 2-passenger Smart and a few sports cars, as well as the over-5 passenger multipurpose van-type vehicles.

Figure 2 gives the index of transport work produced by a unit of fuel energy (taking into account the different energy densities of gasoline and diesel fuels), for the same vehicles and the same driving cycle 
as used for the performance index of Figure 1. It is seen that there is still a large spread between the different model vehicles, but now the best performing vehicles are not solely those of small payloads. In fact, the top performer is a fairly large, diesel engine driven Skoda. Clearly, the inclusion of maximum payload in the evaluation is most relevant for customers actually making use of the payload capacity of their vehicle. If the car is driven most of the time with only one or two persons in it, and with modest amounts of freight, then the vehicles topping Figure 1 may be more appropriate.

\section{Simulation setup}

The simulation uses a mixed driving cycle of total length $89 \mathrm{~km}$ and composed of pieces from European and North American standard cycles (shown at the top of Figures 3 and 4). For the hybrid car, surplus power from the fuel cell is used to recharge the batteries, which at the end of the driving cycle are left as well charged as at the cycle start. The hybrid solution needs a fuel cell rated at $20 \mathrm{~kW}$ with an average efficiency of $50 \%$, plus a $5 \mathrm{kWh}$ Li-ion battery. Both batteries and fuel cells are emerging technologies, as regards efficiency and durability goals. The battery weight is $113 \mathrm{~kg}$ and would be about 2.5 times more for $\mathrm{NiMeH}$ or lead-acid batteries, starting to have a negative effect on performance due to increased overall car weight, in an obviously vicious circle. For comparison, the battery solution for the vehicle in question could not reach the required $650 \mathrm{~km}$ range, and a pure fuel cell vehicle would need a higher rating of $30 \mathrm{~kW}$ [2].

\section{Simulation results}

Figure 3 shows the simulation results for a small hydrogen fuel cell car with a maximum payload of $340 \mathrm{~kg}$ and a $30 \mathrm{~kW}$ mature technology fuel cell [2]. The simulated performance shown (for a typical average loading of $136 \mathrm{~kg}$ of passengers and freight) corresponds to an efficiency performance of $1.17 \mathrm{~km} / \mathrm{MJ}$ or an index of transport work performance of $398 \mathrm{~kg}$ $\mathrm{km} / \mathrm{MJ}$, which is slightly better than the best of current vehicles as seen by comparing with Figure 2. The higher mass of the fuel cell and auxiliary control and battery equipment makes the efficiency advantage over current optimised cars with a common-rail diesel engine and computerised controls very minor.

Figure 4 shows the results of calculations made for a hybrid fuel cell/battery vehicle, again in the popular a-class with a $340 \mathrm{~kg}$ maximum but $136 \mathrm{~kg}$ actual average load of passengers and/or luggage. This car would have a range of $675 \mathrm{~km}$ with $4 \mathrm{~kg}$ of hydrogen stored onboard, under average driving conditions specified by the driving cycle shown at the top of Figure 4 (as compared to $600 \mathrm{~km}$ range for the pure fuel cell car of Figure 3, with the same amount of stored hydrogen). Surplus power from the fuel cell is used to recharge the batteries, which at the end of the driving cycle are left as well charged as at the cycle start. The simulated performance is $1.32 \mathrm{~km} / \mathrm{MJ}$, corresponding to a transport work efficiency index of $448 \mathrm{~kg} \mathrm{~km} / \mathrm{MJ}$, which is substantially higher that what can be achieved by the current car concepts shown in Figure 2 or Table 1.

The hybrid solution needs a fuel cell rated at 20 $\mathrm{kW}$, assuming an average efficiency of $50 \%$, plus a 5 $\mathrm{kWh}$ Li-ion battery. These batteries have only $\mathbf{e}-$ cently become available for automotive uses, and the fuel cell envisaged is rather the goal cell of current $\mathrm{R} \& \mathrm{D}$, in terms of efficiency and assumed life of at least 5 years. At present, the extra cost of $50 \%$ more fuel cells or of a $5 \mathrm{kWH}$ Li ion battery are comparable, and both must come down in order for any of the alternatives to become economically viable. The hybrid solution has a better performance (higher maximum torque and better acceleration characteristics) and even pure fuel cell vehicles are presently most often equipped with a traction-type battery (of say 1 $\mathrm{kWh}$ ).

\section{Conclusions}

The key advantage of the car concept described in Figures 3 and 4 is that it has high efficiency in the conventional sense, before adding a fuel cell/electric motor also of high conversion efficiency. Many current fuel cell prototype cars put $60-100 \mathrm{~kW}$ of fuel cells into a basic car of poor efficiency, which makes little sense considering that the fuel cell cost is the most difficult obstacle. The transport work per unit of energy concept proposed in this paper for appraising vehicle efficiencies has the advantage, that it can be 
applied to both passenger cars, buses and freight trucks, and for looking at the current distribution of efficiencies for various vehicles on the market, in order to form a basis that does not bias against cars with increased passenger- or freight-carrying capacity.

\section{References}

[1] Markel, T. et al. (2002). ADVISOR. J. Power Sources 110, 255-266.
[2] Sørensen, B. (2005). Hydrogen and fuel cells, Elsevier Academic Press, $2^{\text {nd }}$ printing, Boston, $450 \mathrm{pp}$.

[3] Danish Traffic Agency (2005). Nye personbilers energiklasse 2005. http://www.hvorlangtpaaliteren.dk

[4] Car dealer information (2005). Technical data for new cars 2005. http://www.biltorvet.dk/nyebiler/fabrikat.asp

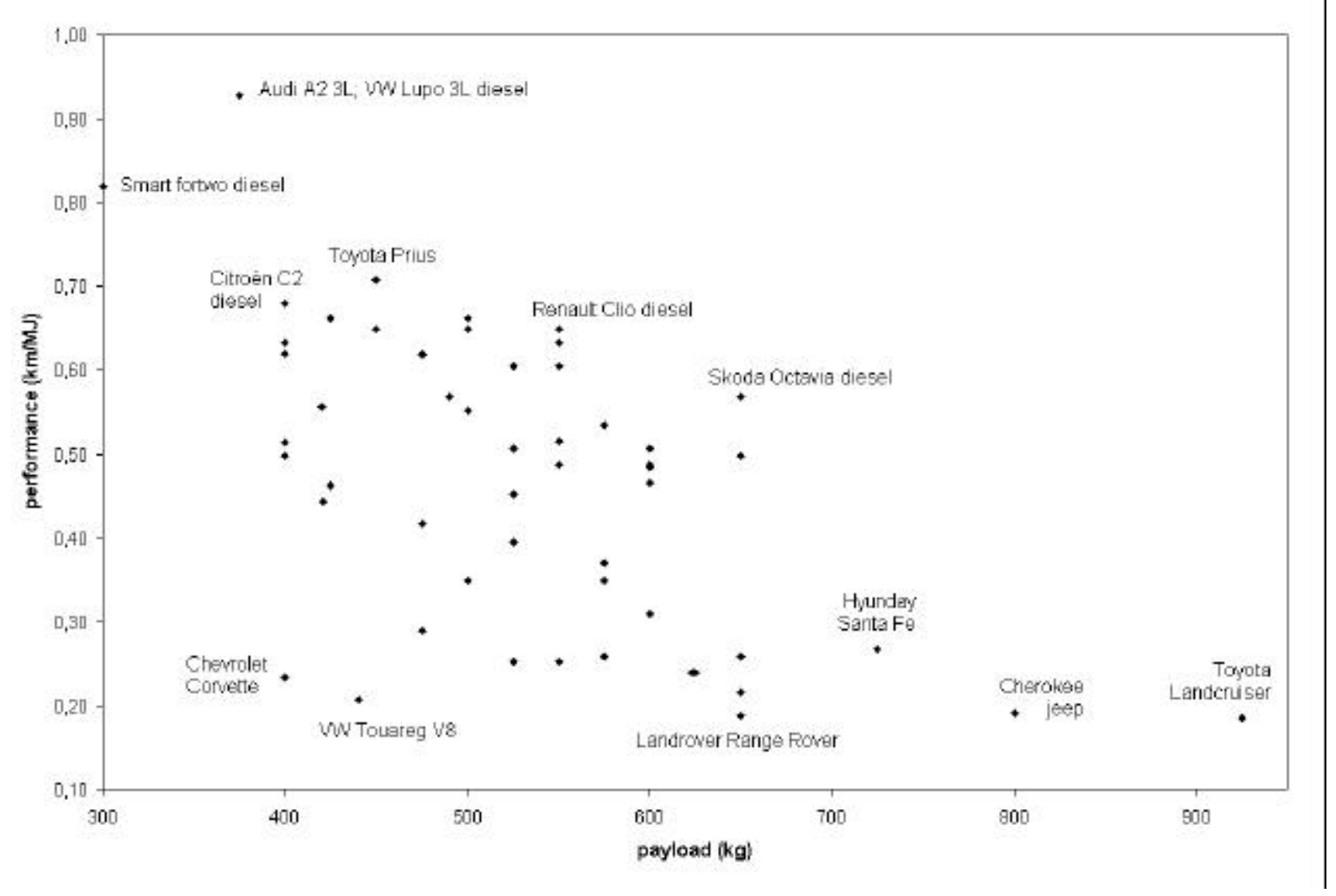

Figure 1. Official 2005 performance data (based on European driving cycle and licensing procedures) for selected passenger cars as function of maximum permitted payload [3, 4]. 


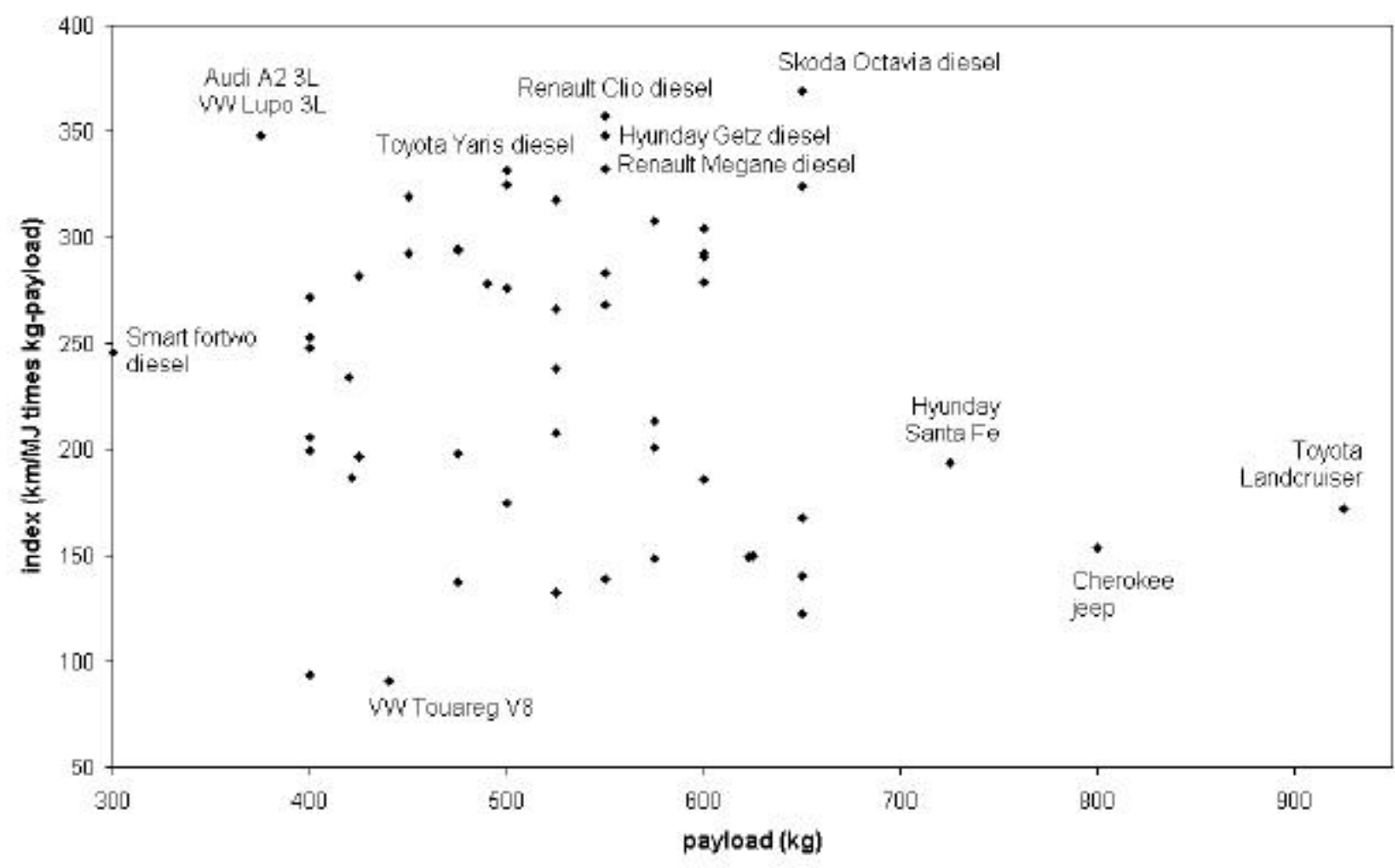

Figure 2. Calculation of transport work efficiency index based upon official 2005 performance data for selected passenger cars as function of maximum permitted payload [3, 4].

Table 1. Selected 2005 passenger vehicles ranked by fuel efficiency $(\mathrm{km} / \mathrm{MJ})$ times maximum payload $(\mathrm{kg})$

\begin{tabular}{|c|c|c|c|c|c|c|c|}
\hline \multicolumn{2}{|l|}{ model ( $d=$ diesel, $o=$ otto engine) } & \multicolumn{2}{|c|}{ kg km/MJ payl. kg } & $\mathrm{r} / \mathrm{MJ}$ & \multicolumn{2}{|c|}{ kW weight kg } & \multirow{2}{*}{$\frac{\boldsymbol{k m} / \mathbf{l}}{20,4}$} \\
\hline Skoda Octavia 1.9 TDI & $d$ & 369,36 & 650 & 0,57 & 77 & 1250 & \\
\hline Renault Clio $1.5 \mathrm{dCl}$ & d & 356,96 & 550 & 0,65 & 48 & 975 & 23,3 \\
\hline Audi A2 3L 1.2TDI aut & $d$ & 347,84 & 375 & 0,93 & 45 & 825 & 33,3 \\
\hline Volkswagen Lupo 1.2 TDI 3L & $d$ & 347,84 & 375 & 0,93 & 45 & 825 & 33,3 \\
\hline Hyundai Getz 1.5 CRDI & $d$ & 347,77 & 550 & 0,63 & 60 & 1050 & 22,7 \\
\hline Renault Megane $1.5 \mathrm{dCl}$ Touring & $d$ & 332,45 & 550 & 0,60 & 60 & 1250 & 21,7 \\
\hline Toyota Yaris 1.4 4D Terra & $d$ & 331,48 & 500 & 0,66 & 55 & 925 & 23,8 \\
\hline Opel Corsa $1.3 \mathrm{CDTI}$ aut & $d$ & 324,51 & 500 & 0,65 & 51 & 1025 & 23,3 \\
\hline Jaguar X-type 2.0 Diesel & $d$ & 324,09 & 650 & 0,50 & 96 & 1375 & 17,9 \\
\hline Toyota Prius 1.5 aut & 0 & 318,69 & 450 & 0,71 & 57 & 1275 & 23,3 \\
\hline Nissan Micra $1.5 \mathrm{~d}$ Cl & $d$ & 317,34 & 525 & 0,60 & 48 & 975 & 21,7 \\
\hline Mercedes-Benz A180 CDI & $d$ & 307,52 & 575 & 0,53 & 80 & 1225 & 19,2 \\
\hline Peugeot 4071.6 HDI part. filter & $d$ & 304,18 & 600 & 0,51 & 80 & 1425 & 18,2 \\
\hline Kia Picanto 1.1 & 0 & 294,53 & 475 & 0,62 & 48 & 875 & 20,4 \\
\hline Mazda 2 1.4 Diesel & $d$ & 293,73 & 475 & 0,62 & 74 & 1050 & 22,2 \\
\hline
\end{tabular}




\begin{tabular}{|c|c|c|c|c|c|c|c|}
\hline Audi A4 1.9 TDI avant & $d$ & 292.48 & 600 & 0.49 & 85 & 1425 & 17.5 \\
\hline Opel Vectra 1.9 CDTI part.filter & d & 292,48 & 600 & 0,49 & 88 & 1425 & 17,5 \\
\hline Fiat Panda 1.3 JTD & $d$ & 292,06 & 450 & 0,65 & 51 & 925 & 23,3 \\
\hline Ford Mondeo 2.0 TDCRi & $d$ & 290,81 & 600 & 0,48 & 85 & 1400 & 17,4 \\
\hline Citroën C5 1.6HDI part.filter & $d$ & 283,43 & 550 & 0,52 & 80 & 1400 & 18,5 \\
\hline Citroën C3 1.4HDI & $d$ & 281,75 & 425 & 0,66 & 52 & 1025 & 23,8 \\
\hline Toyota Avensis 2.0 Diesel D-4D STW & $d$ & 279,11 & 600 & 0,47 & 85 & 1400 & 16,7 \\
\hline Volvo S40 1.6D part. Filter & $d$ & 278,44 & 490 & 0,57 & 81 & 1275 & 20,4 \\
\hline Seat Ibiza 1.9 TDI & $d$ & 275,77 & 500 & 0,55 & 96 & 1175 & 19,8 \\
\hline Citroën C2 1.4HDI & $d$ & 271,87 & 400 & 0,68 & 50 & 1000 & 24,4 \\
\hline BMW 120d & $d$ & 268,11 & 550 & 0,49 & 120 & 1300 & 17,5 \\
\hline BMW 320d sedan & $d$ & 266,16 & 525 & 0,51 & 320 & 1375 & 18,2 \\
\hline Peugeot $10071.4 \mathrm{HDI}$ & $d$ & 252,92 & 400 & 0,63 & 50 & 1172 & 22,7 \\
\hline Suzuki Alto 1.1 & 0 & 248,02 & 400 & 0,62 & 46 & 775 & 20,4 \\
\hline Smart fortwo coupé 0.8 CDI & $d$ & 245,68 & 300 & 0,82 & 30 & 700 & 29,4 \\
\hline Toyota Corolla 1.4 & 0 & 237,77 & 525 & 0,45 & 71 & 1100 & 14,9 \\
\hline Volkswagen Fox diesel & $d$ & 233,98 & 420 & 0,56 & 51 & 1100 & 20 \\
\hline Subaru Legacy 2.0 AWD & 0 & 213,22 & 575 & 0,37 & 121 & 1325 & 12,2 \\
\hline Honda 2.0i Accord Sedan & 0 & 207,45 & 525 & 0,40 & 114 & 1300 & 13 \\
\hline Ford Ka 1.3 & 0 & 205,47 & 400 & 0,51 & 51 & 875 & 16,9 \\
\hline Nissan Primera 2.0 & 0 & 200,99 & 575 & 0,35 & 103 & 1325 & 11,5 \\
\hline Volkswagen Fox gasoline & 0 & 199,39 & 400 & 0,50 & 40 & 1000 & 16,4 \\
\hline Lada 1121.5 Easy & 0 & 197,80 & 475 & 0,42 & 56 & 1000 & 13,7 \\
\hline Chevrolet Matiz 1.0 & 0 & 196,35 & 425 & 0,46 & 47 & 800 & 15,2 \\
\hline Hyundai Sante Fe 2.4 4WD aut & 0 & 193,92 & 725 & 0,27 & 127 & 1700 & 8,8 \\
\hline Volkswagen Golf 1.4 & 0 & 186,83 & 421 & 0,44 & 55 & 1150 & 14,6 \\
\hline BMW 520i aut & 0 & 186,02 & 600 & 0,31 & 125 & 1475 & 10,2 \\
\hline Mazda Premacy 2.0 & 0 & 174,77 & 500 & 0,35 & 96 & 1300 & 11,5 \\
\hline Mitsubishi Lancer 2.0 STW & 0 & 174,77 & 500 & 0,35 & 99 & 1275 & 11,5 \\
\hline Toyota Landcruiser 1004.7 aut & 0 & 171,50 & 925 & 0,19 & 175 & 2300 & 6,1 \\
\hline Mercedes-Benz E500 T aut & 0 & 167,93 & 650 & 0,26 & 225 & 1750 & 8,5 \\
\hline Cherokee jeep Grand 4.7 aut & 0 & 153,19 & 800 & 0,19 & 167 & 1900 & 6,3 \\
\hline Kia Sorento 3.5 V6 aut & 0 & 150,08 & 625 & 0,24 & 143 & 1925 & 7,9 \\
\hline Volvo XC90 T6 aut cross country & 0 & 149,60 & 623 & 0,24 & 200 & 2025 & 7,9 \\
\hline Suzuki Grand Vitara 2.5 aut & 0 & 148,56 & 575 & 0,26 & 135 & 1675 & 8,5 \\
\hline Cadillac SRX 4.6 V8 4x5 aut & 0 & 140,27 & 650 & 0,22 & 239 & 2025 & 7,1 \\
\hline Lexus LS 430 aut & 0 & 138,75 & 550 & 0,25 & 207 & 1800 & 8,3 \\
\hline Crysler PT Cruiser 2.4 aut & 0 & 137,16 & 475 & 0,29 & 105 & 1450 & 9,5 \\
\hline Alfa Romeo 147 GTA 3.2 & 0 & 132,45 & 525 & 0,25 & 184 & 1325 & 8,3 \\
\hline Landrover Range Rover 4.4 aut & 0 & 122,49 & 650 & 0,19 & 210 & 2400 & 6,2 \\
\hline Chevrolet Corvette 6L V8 Coupé & 0 & 93,62 & 400 & 0,23 & 297 & 1425 & 7,7 \\
\hline Volkswagen Touareg 4.2 V8 aut & 0 & 90,94 & 440 & 0,21 & 228 & 2317 & 6,8 \\
\hline Porsche Carrera GT 5.710 cyl. & 0 & 43,40 & 255 & 0,17 & 450 & 1300 & 5,6 \\
\hline
\end{tabular}

Sources : www.hvorlangtpaaliteren.dk; www.biltorvet.dk/nyebiler/fabrikat.asp

Table 1: continued. 

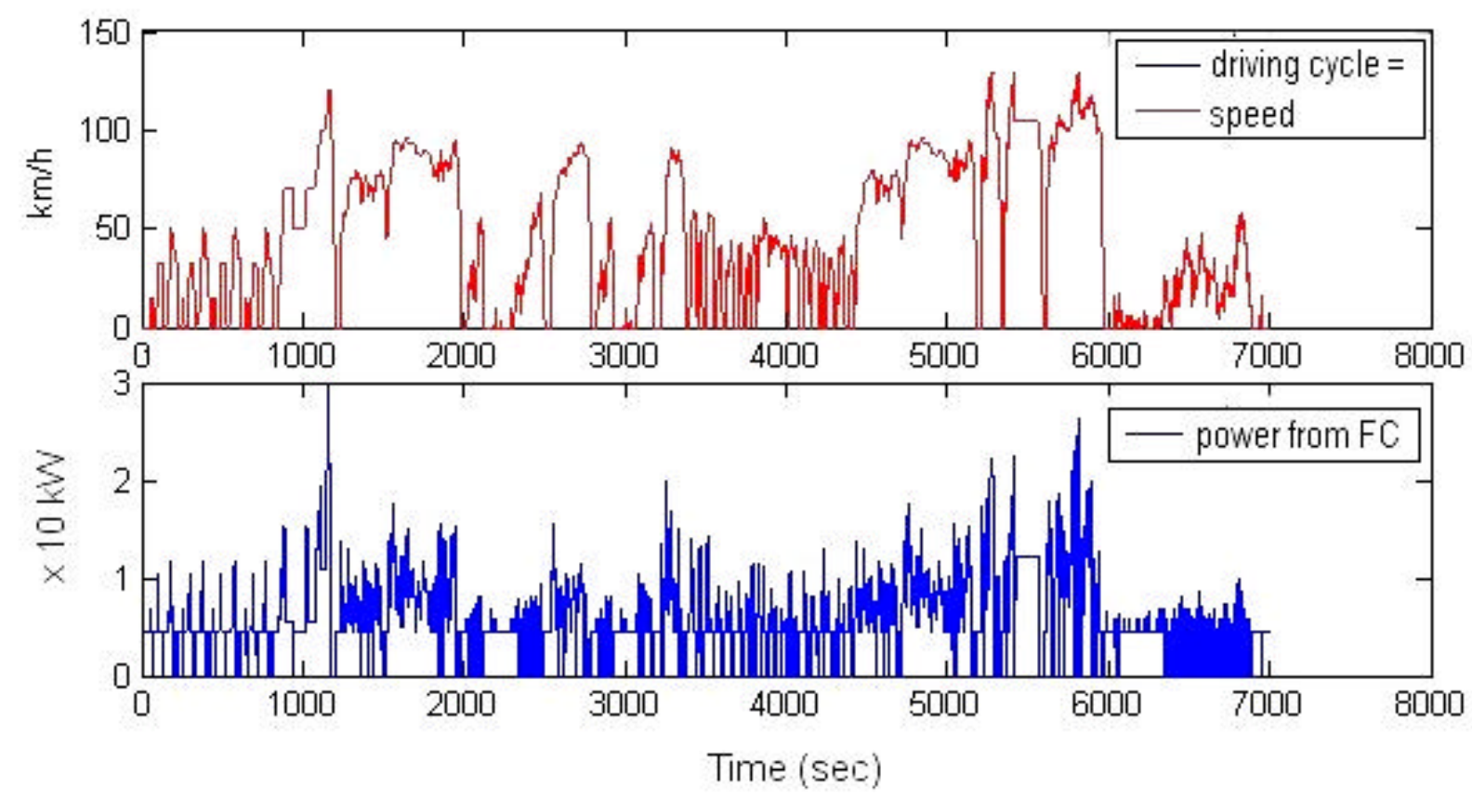

Figure 3. Simulation results for a $30 \mathrm{~kW}$ fuel cell car under the mixed driving cycle shown at top and matching the achieved speed as function of time. The average performance efficiency is $1.17 \mathrm{~km} / \mathrm{MJ}$ and the transport work efficiency is $398 \mathrm{~kg} \mathrm{~km} / \mathrm{MJ}$ [2]. 

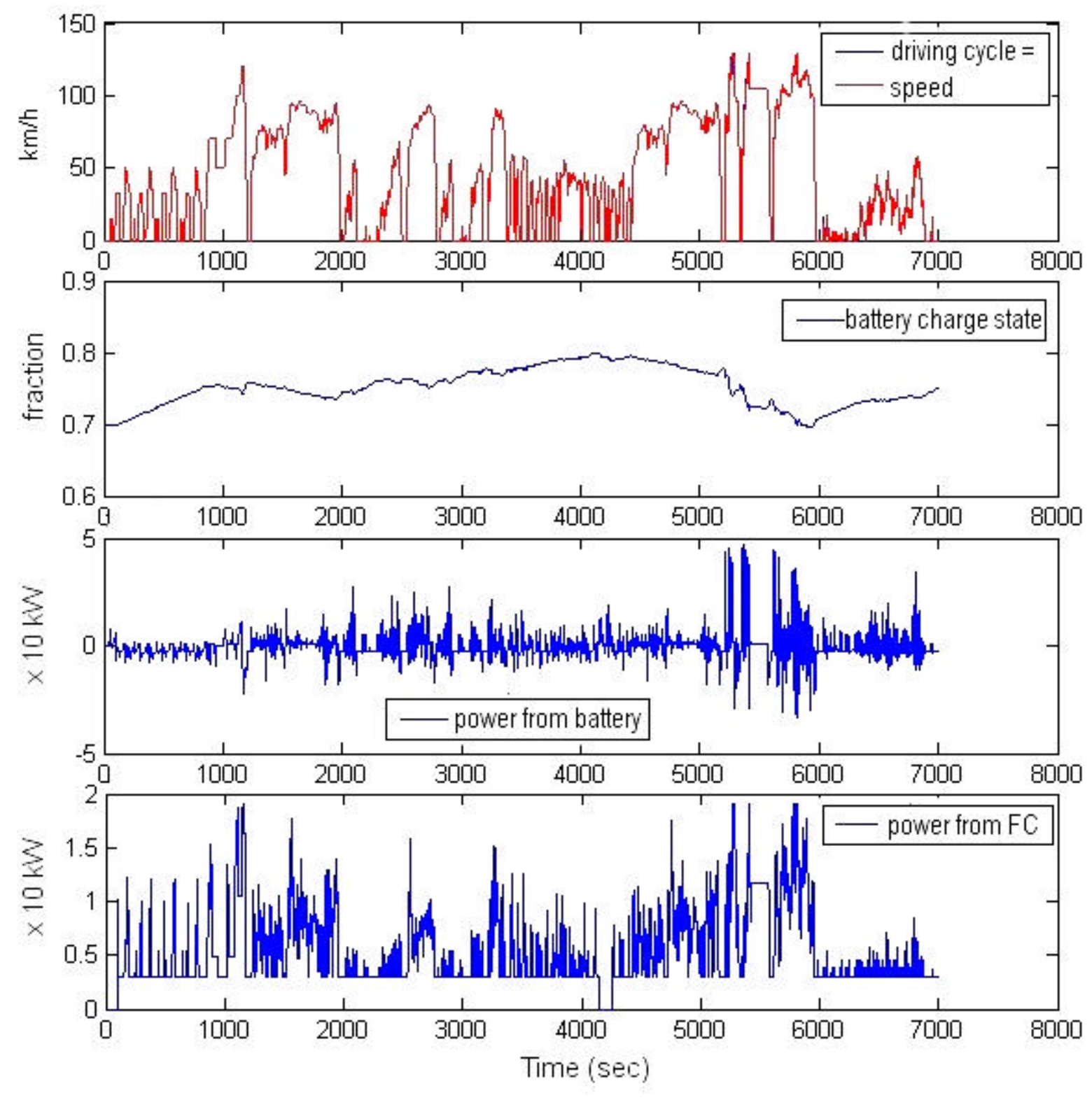

Figure 4. Simulation results for a hybrid car with a $20 \mathrm{~kW}$ fuel cell and a $5 \mathrm{kWh}$ Li-ion battery, under the same driving cycle as used in Figure 3 . The average performance efficiency is now $1.32 \mathrm{~km} / \mathrm{MJ}$ and the transport work efficiency is $448 \mathrm{~kg} \mathrm{~km} / \mathrm{MJ}$ [2]. 